\title{
Pilot Test of Elemental Fingerprint in Otolith Core as a Natural Biological Tag to Discriminate among Gymnocypris przewalskii Stocks in Lake Qinghai in
} Qinghai-Tibet Plateau, China Zhang $\mathrm{JY}^{1 *}$, Liu XH' $\mathbf{X H}^{1}$, Zhao $\mathrm{YL}^{1}$, Wei $\mathrm{FL}^{2}$ and $\mathrm{Li} \mathrm{CZ}^{2 *}$

${ }^{1}$ State Key Laboratory of Freshwater Ecology and Biotechnology, Institute of Hydrobiology, Chinese Academy of Sciences, China ${ }^{2}$ State Key Laboratory of Plateau Ecology and Agriculture College of Ecological and Environmental Engineering, Qinghai University, China

\begin{abstract}
Naked or scaleless carp, Gymnocypris przewalskii as reported by Kessler in 1876 is the unique economic fish species and play an important ecological function to maintain the health ecosystem of Qinghai Lake watershed. The natural resource of naked carp, however, has sharply decreased during the past decades. Understanding the stock structure of this endangered fish is prerequisite to make a scientific management strategy to restore its stock resources. Otolith fingerprint has been widely applied to identify and discriminate fish stocks. In the present work, a pilot test was performed to evaluate the possibility of applying trace element fingerprint of otolith core as a natural tag to discriminate among stocks of two inflowing river and releasing artificially hatched and nursed individuals of naked carp. Results showed that otolith core elemental fingerprinting can successfully discriminate the three analyzed naked carp groups which will provide a robust tool for conservation and future development of aquaculture industry of this economic fish in Qinghai-Tibet plateau.
\end{abstract}

Keywords: Gymnocypris przewalskii; Otolith fingerprint; Stock discrimination; Qinghai-Tibet plateau

\section{Introduction}

Lake Qinghai is the largest inland saltwater lake, locating in the Qinghai-Tibet Plateau of northwestern China at an elevation of 3200. Extreme conditions, including high $\mathrm{pH}$, high salinity and harsh climate make fish species very few. Naked or scaleless carp, Gymnocypris przewalskii was reported by Kessler in 1876 (Cyprinidae: Schizothoracinae) is the unique endemic species which is of most economically and ecologically importance in the Lake Qinghai ecosystem [1,2]. The naked carp resource, however, has sharply decreased from about 200, 000 tons in the 1960s to less than 2,600 tons in the 2002 [3] for global warming and anthropogenic interruption, including overfishing, reduction of hatchery habitat by construction of weirs, irrigation diversions and inflowing rivers running dry and ecological deterioration [2]. G. przewalskii has become an endangered fish species and been listed in China's Red list since 2004 [4]. The depressed status of naked carp not only seriously threats the ecological integrity of symbiotic relationship of fish and birds in Lake Qinghai, but also affects the uptake of fish protein for local residents in Qinghai province. To protect and restore the resources of naked carp, 5 consecutive forbidden fishing periods of 10 years since 1982 and stock enhancement and releasing since 2002 were implemented by the local government $[3,5]$. Recent resource survey by hydroacoustic survey showed the overall fish biomass of naked carp has restored to about 30,000 tons, but far less than original resource $[3,6]$. Further measures should be taken to support the sustainable increasing of naked carp population. Full understanding the stock structure and dynamics of existed naked carp in watershed of Qinghai Lake is prerequisite to make a holistic scientific and reasonable fishery management strategy.

G. przewalskii is an anadromous species which seasonally migrates to inflowing rivers for reproduction from April to July and then return to the lake for growth [7]. Previous studies showed that there were significant genetic differences among naturally produced stocks in different tributaries of Lake Qinghai and suggested that different groups should be treated as separate management units $[5,8]$. As an alternative and synergistic tool with genetic approaches, otolith fingerprint has been widely applied to identify and discriminate fish stocks which is based on the assumption of variation in otolith chemical composition as the proxy of water environment experienced by fish stocks $[9,10]$. Previous report of remarkable differences among water chemical characteristics of the adjoining rivers of Lake Qinghai is the basis of applying otolith microchemistry to discriminate among stocks of naked carp [11]. So, one of purpose of the present work is to test the possibility of applying the elemental composition in the otolith core of naked carp to discriminate among stocks with different natal and nursery sites. Additionally, assessment of the actual contribution of enhancement and releasing activities to the resource restoration of naked carp has not yet been conducted, although this program has been carried out more than 10 years. Taking into account the different water environment between artificially hatchery and nursery and wild water environment, it is possible, we thought, to apply the elemental signatures of otolith core as a natural biological tag to discriminate the artificially releasing fish from naturally produced fish.

As a pilot study, the trace elemental signatures of otolith core of two naturally produced stocks and the artificially spawn and nursed stock were analyzed by laser ablation inductively coupled plasma mass spectrometry (LA-ICPMS) to test this possibility here.

*Corresponding authors: JY Zhang, State Key Laboratory of Freshwater Ecology and Biotechnology, Institute of Hydrobiology, Chinese Academy of Sciences 430072 Wuhan, China, Tel: 86-27-68780007; Fax: 86-27-687800720; E-mail: zhangjy@ihb.ac.cn

${ }^{*} \mathrm{CZ} \mathrm{Li}$, State Key Laboratory of Plateau Ecology and Agriculture College of Ecological and Environmental Engineering, Qinghai University, 810016 Xining China, Tel: 86-971- 5313741; Fax: 86-971-5313741; E-mail: licz05@gmai.com

Received May 13, 2016; Accepted September 19, 2016; Published September 21, 2016

Citation: Zhang JY, Liu XH, Zhao YL, Wei FL, Li CZ (2016) Pilot Test of Elemental Fingerprint in Otolith Core as a Natural Biological Tag to Discriminate among Gymnocypris przewalskii Stocks in Lake Qinghai in Qinghai-Tibet Plateau, China. J Aquac Res Development 7: 447. doi: 10.4172/2155-9546.1000447

Copyright: ( 2016 Zhang JY, et al. This is an open-access article distributed under the terms of the Creative Commons Attribution License, which permits unrestricted use, distribution, and reproduction in any medium, provided the original author and source are credited. 
Citation: Zhang JY, Liu XH, Zhao YL, Wei FL, Li CZ (2016) Pilot Test of Elemental Fingerprint in Otolith Core as a Natural Biological Tag to Discriminate among Gymnocypris przewalskii Stocks in Lake Qinghai in Qinghai-Tibet Plateau, China. J Aquac Res Development 7: 447. doi: 10.4172/2155-9546.1000447

Page 2 of 5

\section{Material and Methods}

\section{Sample collection}

Ten samples of naturally hatched naked carp from Quanji River (QJ) and Shaliu River (SL), two adjacent tributaries of Lake Qinghai were respectively collected with cast net at the peak of the hatching season on June 1 of 2014. Ten artificially hatched and nursed fish fingerlings (AP) which were hatched in a hatchery station at the estuary of SL in May of 2013 and transported to the earth pond for nursery in the Rescue Center of Naked carp in Xining city, the province capital of Qinghai for rearing were also captured by trawl net on July 1, 2015. The geographic co-ordinates of sampling site in QJ and SL can be seen in Figure 1, similar with those of O'Bryan et al. [8]. All artificially fertilized eggs of naked carp obtained from stocks of different inflowing rivers were transported to the artificially hatchery station locating at the estuary of SL within $3 \mathrm{~h}$ after insemination for hatching. The Rescue Center of Naked carp is about $135 \mathrm{~km}$ away from Lake Qinghai (please refer the Figure 1 for the geographical information). All sampled fish were frozen immediately after measuring the body weight (BW) and body length (BL) and transported to the laboratory of Institute of Hydrobiology, Chinese Academy of Sciences in Wuhan city in central China for elemental analysis.

\section{Otolith preparation and elemental analysis}

The otoliths extraction was performed according to the previous report $[12,13]$. Briefly, the sagittal otoliths were removed with acidwashed $\left(0.5 \%\right.$ Optima $\mathrm{HNO}_{3}$, Fisher Inc.) non-metallic forceps, cleaned by sonicating in distilled Milli Q water for $10 \mathrm{~min}$ and then oven-dried overnight at $35^{\circ} \mathrm{C}$ after defrosting, followed by preserving in dry, acid-washed polyethylene boxes until elemental analysis. The longest and shortest axes of the decontaminated otolith were measured to the nearest $1 \mu \mathrm{m}$ under light microscopy (Olympus BX 35) and their weight to the nearest $0.1 \mathrm{mg}$ using an electrical balance (Sartorius BS$124 \mathrm{~S})$. The left otolith of each pair was used for elemental analysis by LA-ICPMS while the right for age determination based on methods of Chen et al. [14]. All fish were sampled after getting the approval of local and national authorities and all procedures were carried out in accordance with animal care regulations issued by Institute of Hydrobiology, Chinese Academy of Sciences. For LA-ICPMS analysis, concentrations of otolith core elements (including $\mathrm{Li}, \mathrm{Na}, \mathrm{Mg}, \mathrm{Al}, \mathrm{K}$, $\mathrm{Ca}, \mathrm{Sc}, \mathrm{Ti}, \mathrm{V}, \mathrm{Cr}, \mathrm{Mn}, \mathrm{Fe}, \mathrm{Co}, \mathrm{Ni}, \mathrm{Cu}, \mathrm{Zn}, \mathrm{Sr}, \mathrm{Cd}, \mathrm{Ba}$ ) were determined on an NW213esi laser ablation system (New Wave Research) coupled with an Agilent 7500ce ICPMS (Agilent Technologies, Tokyo). The laser was operated at a wavelength of $213 \mathrm{~nm}$ with a pulse rate of $10 \mathrm{~Hz}$ and energy density of $9.68 \mathrm{Jcm}^{-2}$. Data were collected by the default Agilent 7,500s ICPMS software and each element presented

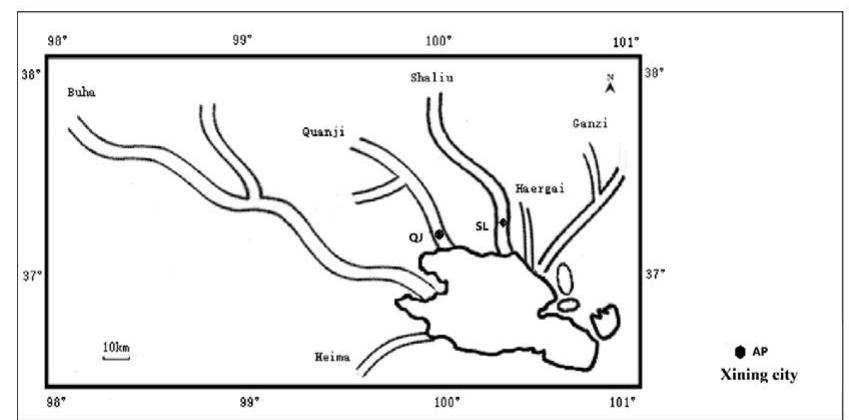

Figure 1: Map of the Qinghai Lake watershed, showing the sampling sites, QL (Quanji River), SL (Shaliu River) and AP (Artificially nursery ponds in Xining city). as a ratio to $\mathrm{Ca}$, corrected for mass bias using calibration standards with known element to Ca ratio. To determine the limits of detection (LOD), blank ablations, only consisting of measuring Ar and He gases were done before and after each analysis session for approximately $120 \mathrm{~s}$ and calculated from three times the standard deviation of this session. Relative standard deviations (\%RSD) based on replicated measurements of the calibration standard, were calculated to reflect the level of precision achieved for each element.

The location of the otolith cores for laser ablating was followed by Dou et al. [15] and ablation spot size was $80 \mu \mathrm{m}$ and a scan speed $30 \mu \mathrm{m} \cdot \mathrm{s}$ ${ }^{1}$. Solid glass standard material from the National Institute of Standards and Technology (NIST 612) was analyzed after every 5 randomized samples besides at the beginning and the end of each analysis session to avoid the possible instrument drift. Data were collected by the default Agilent 7,500s ICPMS software and the concentration of each element was standardized to element: Ca.

\section{Data analysis}

For K and Na were strongly physically regulated, they were excluded for subsequent statistical analysis. All detected elemental concentration ratios above the LOD were firstly examined for within-group normality and then ln-transformed if required and also homogeneity of variances among groups. One-way ANOVA was applied to analyze the univariate differences in concentration ratios of each element among three stocks. The overall differences in the elemental fingerprint among all three groups were tested by MANOVA. Stepwise discriminate function analysis (DFA) was used to test the possibility to discriminate among the naked carp stocks by multi-elements variation in otolith core and identify the element: Ca ratio which contributes the most to fingerprint differences among stocks by plotting the first two discriminate function axes against each other. Statistical analyses were performed on SPSS 22.0 for windows (SPSS Inc.) at a significance level of $\mathrm{p}<0.05$.

\section{Results}

During otolith preparation, some otolith were destroyed and excluded for elemental analysis. The analyzed sample number of SL, $\mathrm{QJ}$ and AP was 7,6 and 7, respectively. The information of naked carp of three stocks for fingerprint analysis of otolith core can be seen in Table 1. The average BL and BW is $182.4 \mathrm{~mm}$ and $64.4 \mathrm{~g}, 189.3 \mathrm{~mm}$, $67.1 \mathrm{~g}$ and $77.1 \mathrm{~mm}$ and $6.2 \mathrm{~g}$ for SL, QJ and AP stock, respectively. Beside Al, Ti, V, Cr and Cd, the concentration of all analyzed element were significant higher than the corresponding LOD. The analytical accuracy for the NIST standard averaged across all samples was high for the remained elements with \%RSD ranged from $7.86\left({ }^{7} \mathrm{Li}\right), 3.92$ $\left({ }^{24} \mathrm{Mg}\right), 5.03\left({ }^{55} \mathrm{Mn}\right), 7.84\left({ }^{57} \mathrm{Fe}\right), 4.91\left({ }^{59} \mathrm{Co}\right), 9.30\left({ }^{60} \mathrm{Ni}\right), 4.76\left({ }^{3} \mathrm{Cu}\right)$, $6.80\left({ }^{66} \mathrm{Zn}\right), 5.09\left({ }^{88} \mathrm{Sr}\right), 6.47\left({ }^{138} \mathrm{Ba}\right)$. The applied element: Ca ratios for statistical analysis fit well the assumptions of within-groups normality (Kolmogorov-Smironv's test, $\mathrm{p}>0.05$ ) and homogeneity of variances among groups (Levene's test, $\mathrm{p}>0.05$ ). One-way ANOVA showed that Li: Ca, Mn: Ca, Sr: Ca and Ba: Ca differed significantly among SL, QJ and AP samples (Table 2). MANOVA also showed significant differences in multi-element fingerprints between all three sample groups $(\mathrm{p}<0.01)$. DFA can effectively discriminate SL, QJ and AP sample groups with classification accuracy rate of $100 \%$ (Figure 2) and Li: Ca and Ba: Ca contributed most to group separation by F-to-remove analysis.

\section{Discussion}

Otolith chemistry has been widely used to address a variety of fishery ecological and conservation issues, including tracking movements in individual fish, discriminating stocks and assessing connectivity 
Citation: Zhang JY, Liu XH, Zhao YL, Wei FL, Li CZ (2016) Pilot Test of Elemental Fingerprint in Otolith Core as a Natural Biological Tag to Discriminate among Gymnocypris przewalskii Stocks in Lake Qinghai in Qinghai-Tibet Plateau, China. J Aquac Res Development 7: 447. doi: $10.4172 / 2155-9546.1000447$

Page 3 of 5

No.

\begin{tabular}{|c|c|}
\hline & BL(mm) \\
\hline 1 & 185 \\
\hline 2 & 196 \\
\hline 3 & 176 \\
\hline 4 & 188 \\
\hline 5 & 193 \\
\hline 6 & 164 \\
\hline 7 & 175 \\
\hline 8 & 192 \\
\hline 9 & 192 \\
\hline 10 & 190 \\
\hline 11 & 182 \\
\hline 12 & 200 \\
\hline 13 & 180 \\
\hline 14 & 79 \\
\hline 15 & 90 \\
\hline 16 & 64 \\
\hline 17 & 83 \\
\hline 18 & 100 \\
\hline 19 & 72 \\
\hline 20 & 52 \\
\hline
\end{tabular}

Fish samples

\begin{tabular}{|c|c|}
\hline BW(g) & Sex \\
\hline 61.2 & + \\
\hline 87.7 & 0 \\
\hline 55.6 & 0 \\
\hline 73.1 & + \\
\hline 61.5 & $q$ \\
\hline 52.6 & 0 \\
\hline 59.0 & + \\
\hline 64.5 & + \\
\hline 68.3 & 0 \\
\hline 66.7 & + \\
\hline 60.7 & 0 \\
\hline 84.5 & 0 \\
\hline 58.1 & $q$ \\
\hline 4.7 & - \\
\hline 9.5 & - \\
\hline 3.2 & - \\
\hline 7.6 & - \\
\hline 12.2 & - \\
\hline 4.3 & - \\
\hline 1.7 & - \\
\hline
\end{tabular}

\section{Otolith}

\begin{tabular}{c}
$\mathbf{W}(\mathbf{m g})$ \\
6.8 \\
8.1 \\
6.7 \\
7.8 \\
8.1 \\
6.7 \\
6.9 \\
\hline 9.7 \\
\hline 9.8 \\
\hline 9.8 \\
\hline 9.5 \\
\hline 9.9 \\
\hline 9.3 \\
\hline 0.88 \\
0.99 \\
0.82 \\
\hline 0.87 \\
0.86 \\
\hline 0.79 \\
\hline 0.62
\end{tabular}

\begin{tabular}{|c|}
\hline $\mathbf{D}_{\max (\mu \mathrm{m})}$ \\
3583 \\
3597 \\
3579 \\
3588 \\
\hline 3596 \\
3519 \\
\hline 3579 \\
\hline 3613 \\
\hline 3672 \\
\hline 3671 \\
\hline 3598 \\
\hline 3710 \\
\hline 3561 \\
\hline 1855 \\
1896 \\
1784 \\
1897 \\
\hline 1923 \\
\hline 1826 \\
\hline 1769
\end{tabular}

\begin{tabular}{|c|}
\hline $\mathbf{D}_{\min (\mu \mathrm{m})}$ \\
2890 \\
2931 \\
2878 \\
\hline 2899 \\
\hline 2906 \\
2769 \\
\hline 2896 \\
\hline 2987 \\
\hline 2991 \\
\hline 2979 \\
\hline 2889 \\
\hline 3010 \\
\hline 2933 \\
\hline 1432 \\
\hline 1513 \\
\hline 1416 \\
\hline 1469 \\
\hline 1537 \\
\hline 1398 \\
\hline 1313
\end{tabular}

Sample site

SL

SL

SL

SL

SL

SL

SL

QJ

QJ

QJ

QJ

QJ

QJ

AP

AP

AP

AP

AP

AP

AP

Table 1: Information of sampled naked carp from two inflowing rivers (Shaliu river, SL and Quanji River, QJ) and an artificially bred freshwater earth pond (AP) for element analysis using LA-ICPMS (BL: Body Length; BW: Body Weight; W: Otolith Weight; $D_{\max }$ : Major Axis Diameter; $D_{\min }$ : Minor Axis Diameter).

\begin{tabular}{|c|c|c|c|c|c|c|}
\hline Element: $\mathrm{Ca}\left(\mathrm{mmol} \mathrm{mol}^{-1}\right)$ & & Sum of Squares & df & MS & $F_{1,20}$ & $\mathbf{P}$ \\
\hline $\mathrm{Li}: \mathrm{Ca}$ & Between Groups & 0.07 & 2 & 0.04 & 34.233 & 0 \\
\hline Mg: Ca & Between Groups & 2.195 & 2 & 1.098 & 1.86 & 0.186 \\
\hline \multirow{3}{*}{$\mathrm{Mn}: \mathrm{Ca}$} & Between Groups & 0 & 2 & 0 & \multirow{3}{*}{5.844} & \multirow{3}{*}{0.012} \\
\hline & Within Groups & 0 & 17 & 0 & & \\
\hline & Total & 0 & 19 & & & \\
\hline \multirow{3}{*}{ Fe: Ca } & Between Groups & 0.001 & 2 & 0 & \multirow{3}{*}{0.246} & \multirow{3}{*}{0.785} \\
\hline & Within Groups & 0.027 & 17 & 0.002 & & \\
\hline & Total & 0.028 & 19 & & & \\
\hline \multirow{3}{*}{ Co: $\mathrm{Ca}$} & Between Groups & 0 & 2 & 0 & \multirow{3}{*}{0.413} & \multirow{3}{*}{0.668} \\
\hline & Within Groups & 0 & 17 & 0 & & \\
\hline & Total & 0 & 19 & & & \\
\hline \multirow{3}{*}{$\mathrm{Ni}: \mathrm{Ca}$} & Between Groups & 0 & 2 & 0 & \multirow{3}{*}{0.187} & \multirow{3}{*}{0.831} \\
\hline & Within Groups & 0.001 & 17 & 0 & & \\
\hline & Total & 0.001 & 19 & & & \\
\hline \multirow{3}{*}{ Cu: Ca } & Between Groups & 0 & 2 & 0 & \multirow{3}{*}{1.195} & \multirow{3}{*}{0.327} \\
\hline & Within Groups & 0 & 17 & 0 & & \\
\hline & Total & 0 & 19 & & & \\
\hline \multirow{3}{*}{$\mathrm{Zn:Ca}$} & Between Groups & 0.001 & 2 & 0.001 & \multirow{3}{*}{0.859} & \multirow{3}{*}{0.44} \\
\hline & Within Groups & 0.011 & 17 & 0.001 & & \\
\hline & Total & 0.012 & 19 & & & \\
\hline \multirow{3}{*}{ Sr: Ca } & Between Groups & 0.032 & 2 & 0.016 & \multirow{3}{*}{5.725} & \multirow{3}{*}{0.013} \\
\hline & Within Groups & 0.048 & 17 & 0.003 & & \\
\hline & Total & 0.08 & 19 & & & \\
\hline \multirow{3}{*}{ Ba: Ca } & Between Groups & 0 & 2 & 0 & \multirow{3}{*}{7.522} & \multirow{3}{*}{0.005} \\
\hline & Within Groups & 0 & 17 & 0 & & \\
\hline & Total & 0 & 19 & & & \\
\hline
\end{tabular}

Table 2: Analysis of variance (ANOVA) results of element: Ca concentration ratios in otolith core regions of naked carp collected from Shaliu River (SL), Quanji River (QJ) and artificially pond (AP).

between nursery grounds and adults stocks [9,10]. However, no application of otolith fingerprint was reported as the natural biological tag to discriminate stocks of naked carp, an endangered unique fish in Qinghai-Tibet Plateau, although EMPA (electron probe microanalysis) was used to explore its migration history $[12,13]$. Naked carp is a migratory fish between inflowing river for reproduction and Lake
Qinghai for grow-out [7]. But whether naked carp are characterized by natal homing and rate of exchangeability of hatching populations of different inflowing rivers remains unknown. Understanding the spatial structure of fish stocks and the connectivity between them has been increasingly considered a crucial requirement for sustainable fisheries management $[15,16]$. So, the development of an effective tag to 
Citation: Zhang JY, Liu XH, Zhao YL, Wei FL, Li CZ (2016) Pilot Test of Elemental Fingerprint in Otolith Core as a Natural Biological Tag to Discriminate among Gymnocypris przewalskii Stocks in Lake Qinghai in Qinghai-Tibet Plateau, China. J Aquac Res Development 7: 447. doi: 10.4172/2155-9546.1000447

Page 4 of 5

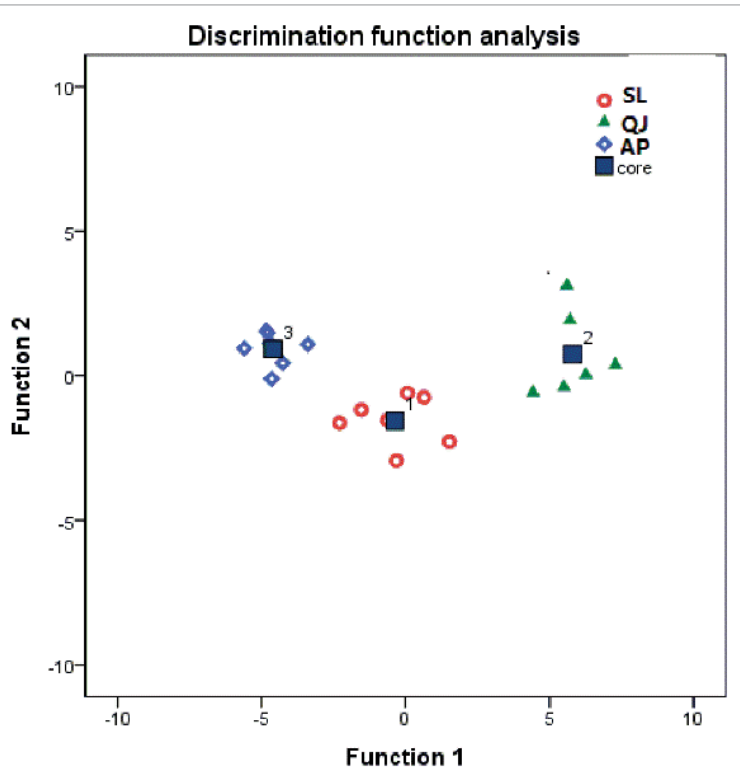

Figure 2: Discriminant function analysis of SL (Shaliu River), QJ (Quanji River) and AP (artificially culture pond) groups based on all measured element: $\mathrm{Ca}$ ratio.

discriminate among populations of naked carp of different spawn and nursery sites is of very importance for sustainable increase of naked carp resource. Previous reports based on genetic markers have proven that some degree of genetic divergence existed among naked carp populations of different tributaries of Lake Qinghai [5,8]. But, straying rate of different populations of naked carp is not easy to determine by solely depending on population genetic markers [8]. Differences of water chemistry features among different spawn and nursery grounds provide a consolidate basis for applying the trace element fingerprint of otolith core to discriminate among stocks of naked carp. In the present work, we firstly test this possibility. The results showed that fingerprint of trace elements deposited in the otolith core can significantly discriminate SL and QJ stocks with $100 \%$ of classification accuracy rate, although we don't know if the differences of water chemistry of these two neighbor rivers exclusively contribute to this classification for many biotic and abiotic factors affect the deposition of trace elements in the otolith.

Additionally, the contribution of the applied stock enhancement and releasing to the increase of naked carp population remains unknown, although recent investigation showed that it was significantly increased after taking measures to prevent and restore them in the past 30 years $[3,6]$. And, it is also unknown if the releasing individuals can sexually mature to develop the stable reproduction population to support restoration of naked carp. No economical and practical tag to discriminate releasing individuals from naturally produced individuals seriously prevents from answering the above questions. Furthermore, the local government of Qinghai province is planning to develop the aquaculture industry of naked carp in the future by taking into account the big market demand of this fish. By that time, a robust tool to discriminate between wild and farmed naked carp is prerequisite to prevent against illegal capture of naked carp in the market. Obviously, analysis of genetic spatial structure cannot differentiate wild from farmed naked carp $[8,16]$. So, development of an appropriate tag is of an important priority.

Although water from SL was drew directly to the artificial hatching station of naked carp in Gangcha country for artificially reproduction, increasing water temperature and application of some disinfectants (including povidone iodine, ferrous sulfate and potassium permanaganate) are general protocols to assure high hatching rate which possibly make the water chemistry differ from the natural SL water [17]. Our previous analysis also showed that some trace elements in artificially hatchery and all natural spawn grounds of naked carp are significantly different (unpublished data). DFA analysis in the present work could significantly discriminate AP sample from SL and QJ with $100 \%$ of success rate, but the centroid of AP group was closer to SL group than QJ group which represented water in artificially hatchery introducing from SL River rather than QJ River to some extent.

\section{Conclusion}

In conclusion, this pilot study shows that elemental signatures of core region of otolith can represents a robust tool to discriminate among different stocks of naked carp in Lake Qinghai catchment which will improve us to get more insight into the stock structure of naked carp. Also, the ability of this too to discriminate the farmed from the naturally produced individuals will be useful to assess the contribution of stock enhancement and releasing to resource restoration of naked carp and support the development of aquaculture of naked carp in the future.

\section{Acknowledgements}

The authors would like to thank Prof. Yang $\mathrm{J}$ and Dr. Jiang $\mathrm{T}$ of Freshwater Fishery Center of Chinese Academy of Fishery Sciences in Wuxi City for their help in element fingerprint analysis. The Science and Technology Department of Qinghai Province provide fund to support this work by 2013-Z-715.

\section{References}

1. Walker KF, Dunn IG, Edwards D, Petr T, Yang HZ (1996) A fishery in a changing lake environment: the naked carp Gymnocypris przewalskii (Kessler) (Cyprinidae: Schizothorzcinae) in Qinghai HU, China. Int J Salt Lake Res 4 169-222.

2. Xiong F, Chen DQ, Duan XB (2010) Threatened fishes of the world: Gymnocypris przewalskii (Kessler, 1876) (Cyprinidae: Schizothoracinae) Environ Biol Fish 87: 351-352.

3. Chen D, Zhang X, Tan K, Wang K, Qiao Y, et al. (2009) Hydroacoustic study of spatial and temporal distribution of Gymnocypris przewalskii (Kessler, 1876) in Qinghai Lake, China. Environ Biol Fish 84: 231-239.

4. Wang S, Xie Y (2004) China species red list, Red list. Higher Education Press Beijing.

5. Wang ZX, Shi JQ, Wei FL, Qi DL, Yuan S, et al. (2015) AFLP genetic diversity of scaleless carp (Gymnocypris przewalskii) in different freshwater tributaries of Qinghai Lake. Geno Appl Biol 34: 82-99.

6. Wang CY, Wei QW, Sun LY, Qi HF, Zhang H, et al. (2013) Distributions and abundance of Gymnocypris przewalskii (Kessler, 1876) in Qinghai Lake, China: an approach based on hydroacoustic sampling. J Appl Ichthyol 29: 1473-1476.

7. Wood CM, Du J, Rogers J, Brauner CJ, Richards JG, et al. (2007) Przewalski's naked carp (Gymnocypris przewalskii): an endangered species taking a metabolic holiday in Qinghai Lake, China. Physiol Biochem Zool 80: 59-77.

8. O'Bryan DM, Xie Z, Wang Y, Du J, Brauner CJ, et al. (2010) Phylogeography and conservation genetics of Lake Qinghai scaleless carp (Gymnocypris przewalskii). J Fish Biol 77: 2072-2092.

9. Campana SE (1999) Chemistry and composition of fish otoliths: pathways, mechanisms and applications. Mar Ecol Prog Ser 188: 263-297.

10. Tanner SE, Reis-Santos P, Cabral HN (2016) Otolith chemistry in stock delineation: A brief overview, current challenges and future prospects. Fish Res 173: 206-213.

11. Zhang F, Jin ZD, Hu G (2009) Seasonally chemical weathering and $\mathrm{CO}_{2}$ consumption flux of Lake Qinghai river system in the northeastern Tibetan Plateau. Environ Earth Sci 59: 297-313. 
Citation: Zhang JY, Liu XH, Zhao YL, Wei FL, Li CZ (2016) Pilot Test of Elemental Fingerprint in Otolith Core as a Natural Biological Tag to Discriminate among Gymnocypris przewalskii Stocks in Lake Qinghai in Qinghai-Tibet Plateau, China. J Aquac Res Development 7: 447. doi: $10.4172 / 2155-9546.1000447$

Page 5 of 5

12. Zhou L, Jin ZD, Li FC (2012) Mineralogy of the otoliths of naked carp Gymnocypris przewalskii (Kessler) from Lake Qinghai and its $\mathrm{Sr} / \mathrm{Ca}$ potentia implications for migratory pattern. Sci China Earth Sci 55: 983-990.

13. Liu HB, Jiang T, Tan XC, Yang J (2012) Preliminary investigation on otolith microchemistry of naked carp (Gymnocypris przewalskii) in Lake Qinghai, China. Environ Biol Fish 95: 455-461.

14. Xiong F, Chen DQ, Liu SP, Duan XB, Shi JQ (2006) Annuli characteristics of the different ageing amterials of Gymnocypris przewalskii przewalskii (Kessier). Acta Hydrobio Sinica, 30: 185-191.
15. Dou SZ, Amano Y, Yu X, Cao L, Shirai K, et al. (2012) Elemental signature in otolith nuclei for stock discrimination of anadromous tapertail anchovy (Coilia nasus) using laser ablation ICPMS. Environ Biol Fish 95: 431-443.

16. Zite A, Sturm M, Waidbacher H, Prohaska T (2010) Discrimination of wild and hatchery trout by natural chronological patterns of elements and isotopes in otoligh using LA-ICP-MS. Fisheries Manag Ecol 17: 435-445.

17. Shi JQ, Qi HF, Yang JX, He WH, Hao GC (2000) Study on reproductive biology of Gymnocypris przewalskii. Qinghai Sci Tec7: 12-15. 